\title{
Vulvar basal cell carcinoma: clinical features and treatment outcomes from a tertiary care centre
}

Rama $P$ Namuduri ${ }^{1}$, MD, MrCog, Timothy YK $\underline{\operatorname{Lim}}^{1}$, FrCog, LLM, Philip KL $\underline{\text { Yam }}^{1}$, MMed, FrCog, Rene $\underline{G a t s i n g a}^{2}$, MPH, Soo Kim Lim-Tan ${ }^{3}$, FRCPath, FCAP, Sung Hock $\underline{\mathrm{Chew}}^{3}$, FRCPA, Mark JA Koh${ }^{4}$, MRCPCH, FAMS, Sorsiah Mansor ${ }^{3}$, MBBCh BAO, FRCPath

\begin{abstract}
We retrospectively reviewed the clinical features, management and outcomes of patients diagnosed with basal cell carcinoma (BCC) of the vulva at the Gynaecological Cancer Centre, KK Women's and Children's Hospital, Singapore, between 1 January 2000 and 28 February 2014. Patients with vulvar BCC were identified from the cancer registry, and their medical records reviewed and analysed. A total of 11 patients with vulvar BCC were identified. Mean age at diagnosis was 63 (range 30-85) years. Ethnically, ten patients were Chinese and one was Malay. Average time from onset of symptoms to diagnosis was 13.8 (range 2-60) months. The most common presenting symptoms were lump and pruritus. All patients were managed surgically. Recurrence was noted in only one patient. Vulvar BCC, although rare, has an excellent prognosis when managed appropriately. Histological diagnosis of all persistent papules, plaques and pigmented lesions is important for early diagnosis.
\end{abstract}

Keywords: basal cell carcinoma, neoplasm, vulvar

\section{INTRODUCTION}

Basal cell carcinoma (BCC), the commonest skin cancer in humans, is highly curable. However, BCC of the vulva accounts for less than $1 \%$ of all BCCs. ${ }^{(1)}$ A majority of BCCs are observed on sun-exposed skin, with nearly $85 \%$ of tumours occurring in the head and neck region. BCC is associated with damage caused by exposure to sunlight and radiation, arsenic ingestion, immunosuppression and inherited conditions, such as xeroderma pigmentosum and nevoid BCC syndrome. ${ }^{(2,3)}$ This neoplasm is thought to arise from stem cells within hair follicles. ${ }^{(4)}$ Histologically, most BCCs can be subtyped into superficial spreading, nodular, micronodular, fibroepithelial or infiltrating variants. In this study, we describe 11 patients diagnosed with vulvar BCC at our centre over a period of 14 years.

\section{CASE SERIES}

With institutional review board approval, we retrospectively identified women treated for vulvar BCC from the cancer registry maintained at the Gynaecological Cancer Centre, KK Women's and Children's Hospital, Singapore, from 1 January 2000 to 28 February 2014. We reviewed the medical records of these patients for clinical characteristics, histopathological reports, past and concurrent medical conditions, types of treatment received, length of follow-up and overall survival outcomes.

In total, we identified 11 patients with vulvar BCC from the cancer registry (Table I). Ten patients were of Chinese ethnicity and one patient was Malay. Mean age at diagnosis was 63 (range 30-85) years. The time from onset of symptoms to diagnosis ranged from 2-60 months. The most common presenting symptoms were an asymptomatic vulvar lump in 7 (63.6\%) patients and vulvar pruritus in $4(36.4 \%)$ patients. The lesion was on the labia majora in 10 (90.9\%) patients and peri-clitoral in $1(9.1 \%$ ) patient. Mean size of lesions was 2.3 (range $0.5-4.0) \mathrm{cm}$.

The diagnoses were confirmed by a Keyes' punch biopsy and managed with definitive surgery. The forms of surgery offered were wide local excision (WLE) for 4 (36.4\%) patients, radical local excision for 1 (9.1\%) patient, hemivulvectomy for $3(27.3 \%)$ patients, simple vulvectomy for 1 (9.1\%) patient, right hemivulvectomy with right groin lymph node dissection for $1(9.1 \%)$ patient and radical vulvectomy with groin lymph node dissection for $1(9.1 \%)$ patient.

For the purposes of the present study, WLE referred to circumferential excision of lesion with an approximate margin of $1 \mathrm{~cm}$ at a depth of the full thickness of the skin and subcutaneous adipose tissue. Radical local excision indicated a wide and deep excision of primary tumour with 1-cm margin, deep to the inferior fascia of the urogenital diaphragm. Simple or total vulvectomy referred to removal of the entire vulva together with the subcutaneous tissue. Hemivulvectomy was the removal of a part of the vulva, including some subcutaneous tissue. Radical vulvectomy referred to the removal of the entire vulva down to the level of the inferior fascia of the urogenital diaphragm.

Histopathologically, 9 (81.8\%) out of 11 patients were found to have the nodular subtype of vulvar BCC. Ten patients had negative margins on histology after the primary surgery. The patient with positive margin, a 78-year-old woman, developed local recurrence two years after her primary surgery - left vulvectomy - and was subsequently managed with re-excision with clear margins. There was no reported recurrence in our patients during 11 years of follow-up. All patients had negative margins after surgery, with clearance in the range of $0.4-5 \mathrm{~mm}$. To date, all patients are alive without recurrence.

${ }^{1}$ Department of Gynaecological Oncology, KK Women's and Children's Hospital, ${ }^{2}$ Duke-NUS Medical School, ${ }^{3}$ Department of Pathology and Laboratory Medicine, ${ }^{4}$ Department of Dermatology, KK Women's and Children's Hospital, Singapore

Correspondence: Dr Rama P Namuduri, Staff Physician, Department of Gynaecological Oncology, KK Women's and Children’s Hospital, 100 Bukit Timah Road, Singapore 229899. rama.padmavathi@kkh.com.sg 
Table I. Presentations, tumour characteristics and outcome of patients with vulvar basal cell carcinoma.

\begin{tabular}{|c|c|c|c|c|c|c|c|}
\hline No. & $\begin{array}{l}\text { Age } \\
\text { (yr) }\end{array}$ & Site of lesion & $\begin{array}{l}\text { Size } \\
(\mathrm{cm})\end{array}$ & Symptoms and signs & Treatment & Pathology & $\begin{array}{l}\text { Disease-free } \\
\text { interval }\end{array}$ \\
\hline 1 & 67 & Left labia majora & 1 & Pigmented nodule; $6 \mathrm{mth}$ & WLE & Nodular & $11 \mathrm{yr}$ \\
\hline 2 & 73 & $\begin{array}{l}\text { Right labia } \\
\text { majora }\end{array}$ & 1 & Pigmented nodule; $7 \mathrm{mth}$ & WLE & $\begin{array}{l}\text { Multifocal } \\
\text { superficial }\end{array}$ & $2 \mathrm{yr}$ \\
\hline 3 & 56 & Peri-clitoral & 2 & $\begin{array}{l}\text { Pigmented papule, } \\
\text { pruritus and bleeding for } \\
6 \mathrm{mth}\end{array}$ & Simple vulvectomy & $\begin{array}{l}\text { Nodular, 1.5-mm } \\
\text { deep }\end{array}$ & $8 \mathrm{yr}$ \\
\hline 4 & 55 & Left labia majora & 2 & $\begin{array}{l}\text { Erythematous plaque; } \\
60 \mathrm{mth}\end{array}$ & $\begin{array}{l}\text { Left } \\
\text { hemivulvectomy }\end{array}$ & $\begin{array}{l}\text { Nodular, cystic } \\
\text { type }\end{array}$ & $9 \mathrm{yr}$ \\
\hline 5 & 78 & Left labia majora & 3 & Nodule; $3 \mathrm{mth}$ & $\begin{array}{l}\text { Left } \\
\text { hemivulvectomy }\end{array}$ & Nodular & $\begin{array}{l}11 \mathrm{yr} \text { from } \\
\text { recurrence }\end{array}$ \\
\hline 6 & 77 & $\begin{array}{l}\text { Upper left labia } \\
\text { majora }\end{array}$ & 3 & $\begin{array}{l}\text { Nodule; } 36 \mathrm{mth} \text {; } \\
\text { associated with pruritus } \\
\text { and bleeding }\end{array}$ & $\begin{array}{l}\text { Radical wide } \\
\text { excision }\end{array}$ & $\begin{array}{l}\text { Nodular, infiltrative } \\
\text { with squamous } \\
\text { differentiation }\end{array}$ & $5 \mathrm{yr}$ \\
\hline 7 & 85 & $\begin{array}{l}\text { Right labia } \\
\text { majora }\end{array}$ & 1.5 & Pigmented nodule; $6 \mathrm{mth}$ & $\begin{array}{l}\text { Right } \\
\text { hemivulvectomy }\end{array}$ & $\begin{array}{l}\text { Nodular, associated } \\
\text { with lichen } \\
\text { sclerosus }\end{array}$ & $6 \mathrm{yr}$ \\
\hline 8 & 43 & Left labia majora & 2 & Nodule; $8 \mathrm{mth}$ with itch & WLE & Nodular, cystic & $2 \mathrm{yr}$ \\
\hline 9 & 63 & $\begin{array}{l}\text { Right labia } \\
\text { majora }\end{array}$ & 1.5 & Skin tag-like lesion; $4 \mathrm{mth}$ & WLE & $\begin{array}{l}\text { Nodular, with focal } \\
\text { infiltrative patterns }\end{array}$ & $2 \mathrm{yr}$ \\
\hline 10 & 30 & $\begin{array}{l}\text { Right and left } \\
\text { labia majora }\end{array}$ & 4 & Pigmented nodule; $2 \mathrm{mth}$ & $\begin{array}{l}\text { Radical } \\
\text { vulvectomy and } \\
\text { GLND }\end{array}$ & $\begin{array}{l}\text { Nodular, with } \\
\text { squamous } \\
\text { differentiation }\end{array}$ & $11 \mathrm{yr}$ \\
\hline 11 & 69 & $\begin{array}{l}\text { Plaque on right } \\
\text { labia majora }\end{array}$ & $3-4$ & Hypopigmented plaque & $\begin{array}{l}\text { Right } \\
\text { hemivulvectomy } \\
\text { and right GLND }\end{array}$ & $\begin{array}{l}\text { Mixed nodular, } \\
\text { possibly } \\
\text { micronodular and } \\
\text { infiltrative type }\end{array}$ & $4 \mathrm{mth}$ \\
\hline
\end{tabular}

GLND: groin lymph node dissection; WLE: wide local excision

No other forms of treatment, such as chemotherapy or radiotherapy, was offered to any patient. For all 11 patients, no concurrent skin malignancy or other malignancies were reported. At the time of writing, our patients had follow-up durations ranging from four months to 13 years.

\section{DISCUSSION}

BCC is a non-melanocytic epithelial tumour that arises from basal cells, which are found in the lower layer of the epidermis. BCCs often occur on sun-exposed skin of the head and neck in older, lighter-skinned individuals. It is a slow-growing tumour that rarely metastasises.

In Singapore, skin cancer is the seventh most common type of cancer, with an annual BCC incidence rate of nine per 100,000 individuals. ${ }^{(5)}$ This observed annual incidence rate is very low when compared with countries that have predominantly fair-skinned populations. ${ }^{(6)}$ The differences in the clinical characteristics and rates of BCC on sun-exposed skin can be associated with variations in factors that increase cumulative lifetime ultraviolet radiation damage, such as skin type, geographical region, occupational exposure, lifestyle, frequency of childhood sunburn and health literacy. BCCs of sun-protected skin, on the other hand, are thought to be due to chronic irritation and inflammation secondary to the likes of lichen sclerosus in the case of vulvar BCC. ${ }^{(7,8)}$ Genetic conditions, such as a sonic hedgehog receptor defect or a patched gene defect, are known to be associated with higher BCC incidence on both sun-exposed and sun-protected skin, and could therefore predispose one to vulvar BCC.

The reported age at presentation for vulvar BCC in the literature ranges from the mid-30s to late-90s, with an average patient age of 70 years. ${ }^{(9,10)}$ The age of our cohort (mean age: 63 [range 30-85] years) was comparable to these previous studies. Interestingly, however, Fleury et al has recently reported a case of vulvar BCC in a 20-year-old woman. ${ }^{(10)}$

The lesions in our series were located on the labia majora (10/11 patients, $90.9 \%$ ) and in the peri-clitoral area (1/11 patient, 9.1\%). The clinical size of our lesions (mean size: $2.3 \mathrm{~cm}$ ) was also comparable to those reported in similar studies. ${ }^{(9,10)}$ Among our patients, $8(72.7 \%)$ presented with nodular appearance, $5(62.5 \%)$ of which were pigmented. This was also according to expectations, as it has been documented that vulvar BCC nodules are predominantly pigmented in individuals of Chinese ancestry. ${ }^{(11)}$ All the other forms of presentations we observed - erythematous plaques, skin tag-like lesions, pruritus and bleeding - are known common forms of presentation of vulvar BCC. Of note, none of our patients presented with an ulcerated lesion, which is an otherwise commonly documented presenting sign. ${ }^{(10,11)}$

A diagnosis of vulvar BCC might be delayed because of its slow progression and its atypical presentation in the vulvar area. 
They should be differentiated from other pigmented lesions, such as sebaceous hyperplasia, nevi, malignant melanoma, keratoacanthoma or seborrheic keratosis. The delay in presentation in our study ranged from two months to five years. In some reported cases, diagnoses have been delayed for as long as 20 years. ${ }^{(9,12,13)}$ In our study, the average time from the onset of symptoms to diagnosis was 13.8 months, which is consistent with other studies. ${ }^{(13)}$

A skin punch biopsy is required to confirm the diagnosis and determine the histopathological subtype of BCC. On the other hand, pigmented lesions that are difficult to distinguish from melanoma may require an excisional biopsy to assess the depth of the lesion. Several histological patterns have been reported. ${ }^{(14)}$ BCCs are pathologically classified as nodular, micronodular, fibroepithelial, superficial and infiltrative, each with a distinct biological behaviour. Less common variants include BCC with adnexal differentiation, keratotic, infundibulocystic, pigmented and others. The nodular type is the most common overall. Ramdial et al reported that superficial and nodular BCCs are indolent slowgrowing tumours when compared with the aggressive infiltrating/ morphoeic variants. ${ }^{(15)}$ Morphoeic, infiltrating, basosquamous, adenocystic subtypes and perineural invasion are associated with higher recurrence rates. ${ }^{(15,16)}$ Only one of our patients had BCC with squamous differentiation; she was treated with radical vulvectomy.

Most of our patients were diagnosed with the nodular subtype of BCC. It is defined by lobules of basaloid cells, with peripheral palisading nuclei and scattered mitoses associated with surrounding loose myxoid/fibrous stroma. Artifactual retraction spaces between the tumour and stroma (Fig. 1) are often present in nodular BCC. The infiltrating variant shows strands, cords and columns of basaloid cells with scant cytoplasm. Peripheral palisading and retraction spaces are uncommon in infiltrative BCC. Superficial BCC consists of superficial lobules of basaloid cells, which project from the epidermis (Fig. 2). It tends to be multifocal. Basosquamous carcinoma is essentially BCC with squamous differentiation. Mixed patterns, particularly nodular, micronodular or infiltrative components, are not uncommon. ${ }^{(16,17)}$

The treatment of BCC can be surgical or non-surgical. Surgical techniques include curettage, cautery, cryosurgery, Mohs micrographic surgery and complete surgical excision. Mohs micrographic surgery has been recommended by some as the method of choice. ${ }^{(17)}$ Even so, wide surgical excision is considered adequate treatment for most instances of vulvar BCCs. Local recurrence, possibly due to inadequate margins, is still seen in about $10 \%-20 \%$ of patients. ${ }^{(9,13)}$

BCC rarely metastasises and is usually not staged unless the cancer is very large and is suspected to have spread to other parts of the body. BCC staging is similar to the staging of squamous cell carcinoma. ${ }^{(18)}$ About ten patients with metastasis of vulvar BCC have been reported in the literature. Rare aggressive histologic subtypes (e.g. morphoeic, infiltrating and basosquamous BCC) and large primary tumours (size $>2 \mathrm{~cm}$ ) may be associated with an increased chance of metastasis. ${ }^{(18,19)}$ A recurrence of $\mathrm{BCC}$ should be suspected when the previous excision scar is surrounded by

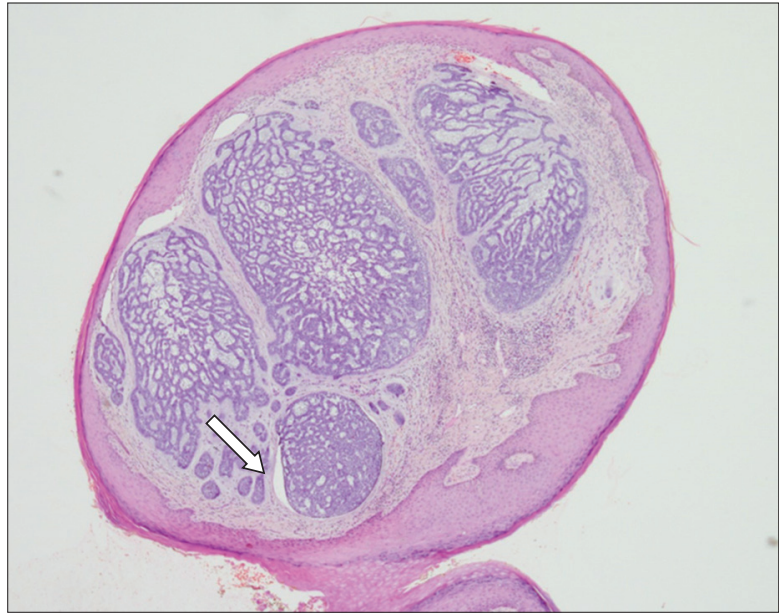

Fig. 1 Photomicrograph shows well-circumscribed nodules with surrounding loose fibromyxoid stroma and characteristic tumour retraction (arrow) (Haematoxylin \& eosin, $\times 4$ ).

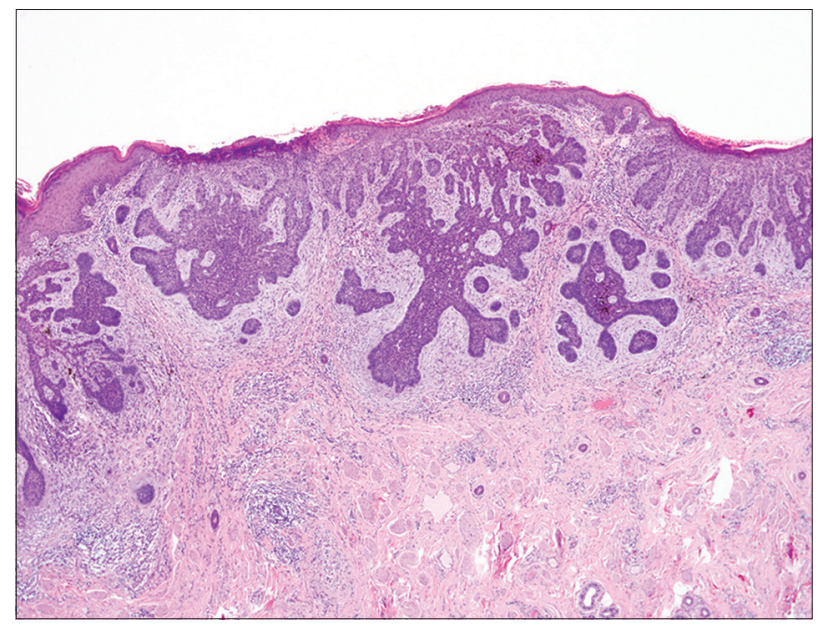

Fig. 2 Photomicrograph shows tumour arising from the basal layer of the epidermis (Haematoxylin \& eosin, $\times 10$ ).

indurations or ulceration. Although high local recurrence rates are reported after simple excision, the use of radical surgeries as primary procedure remains controversial. ${ }^{(20)}$

One of our patients was offered radical vulvectomy with groin lymphadenectomy in view of the large size of the primary lesion and squamous histological differentiation. Another patient was offered a hemivulvectomy with ipsilateral groin lymphadenectomy because of the large size of the primary lesion and mixed histological pattern. As a general rule, however, vulvar BCCs tend to have a rather indolent development pattern and radical surgery is only recommended for patients with deep, extensive, unfavourable histological types. At the time of reporting, none of our patients had experienced metastasis of BCC; neither were there any fatal outcomes.

In conclusion, vulvar BCCs remain a rare tumour of the vulva, which has excellent prognosis if managed appropriately. Any persistent papular or nodular lesion in the vulvar region, especially when pigmented, should be biopsied and examined histologically irrespective of the age of the patient. Clinicians should exercise caution while attending to patients presenting with these symptoms, as vulvar BCCs can easily be misdiagnosed 
because of its similarity to common benign nodular and ulcerative lesions on the vulva as well as skin tags.

\section{REFERENCES}

1. Pisani C, Poggiali S, De Padova L, Andreassi A, Bilenchi R. Basal cell carcinoma of the vulva. J Eur Acad Dermatology Venereol 2006; 20:446-8.

2. Young LC, Listgarten J, Trotter MJ, Andrew SE, Tron VA. Evidence that dysregulated DNA mismatch repair characterizes human nonmelanoma skin cancer. Br J Dermatol 2007; 158:59-69.

3. Couvé-Privat S, Bouadjar B, Avril MF, Sarasin A, Daya-Grosjean L. Significantly high levels of ultraviolet-specific mutations in the smoothened gene in basal cell carcinomas from DNA repair-deficient xeroderma pigmentosum patients. Cancer Res 2002; 62:7186-9.

4. Peterson SC, Eberl M, Vagnozzi AN, et al. Basal cell carcinoma preferentially arises from stem cells within hair follicle and mechanosensory niches. Cell Stem Cell 2015; 16:400-12.

5. Koh D, Wang H, Lee J, et al. Basal cell carcinoma, squamous cell carcinoma and melanoma of the skin: analysis of the Singapore Cancer Registry data 1968-97. Br J Dermatol 2003; 148:1161-6.

6. Wu S, Han J, Li WQ, Li T, Qureshi AA. Basal-cell carcinoma incidence and associated risk factors in U.S. women and men. Am J Epidemiol 2013; 178:890-7.

7. Thomas RH, McGibbon DH, Munro DD. Basal cell carcinoma of the vulva in association with vulval lichen sclerosus et atrophicus. J R Soc Med 1985; 78 Suppl 11:16-8.

8. Jones ISC, Crandon A, Sanday K. Vulvar basal cell carcinoma: a retrospective study of 29 cases from Queensland. Open J Obstet Gynecol 2012; 2:136-9.

9. Benedet JL, Miller DM, Ehlen TG, Bertrand MA. Basal cell carcinoma of the vulva: clinical features and treatment results in 28 patients. Obstet Gynecol 1997; 90:765-8.

10. Fleury AC, Junkins-Hopkins JM, Diaz-Montes T. Vulvar basal cell carcinoma in a 20-year-old: case report and review of the literature. Gynecol Oncol Case Rep 2011; 2:26-7.

11. Lui PC, Fan YS, Lau PP, et al. Vulvar basal cell carcinoma in China: a 13-year review. Am J Obstet Gynecol 2009; 200:514.e1-5.

12. Mulayim N, Foster Silver D, Tolgay Ocal I, Babalola E. Vulvar basal cell carcinoma: two unusual presentations and review of the literature. Gynecol Oncol 2002; 85:532-7.

13. Feakins RM, Lowe DG. Basal cell carcinoma of the vulva: a clinicopathologic study of 45 cases. Int J Gynecol Pathol 1997; 16:319-24.

14. Kurman RJ, Carcangiu ML, Herrington CS, Young RH. WHO Classification of Tumours of Female Reproductive Organs. 4th ed. Geneva: World Health Organization, 2014

15. Ramdial PK, Madaree A, Reddy R, Chetty R. bcl-2 protein expression in aggressive and non-aggressive basal cell carcinomas. J Cutan Pathol 2000; 27:283-91.

16. Motegi SI, Tamura A, Tanaka S, Nagai K, Ishikawa O. Aggressive basal cell carcinoma with pulmonary metastases. Eur J Dermatol 2006; 16:585-6.

17. Saini R, Sarnoff DS. Basal cell carcinoma of the vulva presenting as unilateral pruritus. J Drugs Dermatol 2008; 7:288-90.

18. Tyring SK. Vulvar squamous cell carcinoma: guidelines for early diagnosis and treatment. Am J Obstet Gynecol 2003; 189(3 Suppl):S17-23.

19. Winkelmann SE, Llorens AS. Metastatic basal cell carcinoma of the vulva. Gynecol Oncol 1990; 38:138-40.

20. de Giorgi V, Salvini C, Massi D, Raspollini MR, Carli P. Vulvar basal cell carcinoma: retrospective study and review of literature. Gynecol Oncol 2005; 97:192-4. 